\title{
ABSTRAK \\ RITUAL KEAGAMAAN MASYARAKAT ALIFURU DESA LEKU KECAMATAN NAMROLE KABUPATEN BURU SELATAN
}

Amin Ramly, Dosen Fakultas MIPA UNPATTI Ambon, 085242054751, E-mail: aminramly70@yahoo.co.id

\begin{abstract}
Masyarakat Alifuru juga mempunyai berbagai ritual diantaranya ritual sunatan, perkawinan, kematian, dan lainnya. Namun yang menarik untuk di teliti karena masyarakat Alifuru sampai saat ini belum beragama tetapi mereka mempunyai ritual-ritual yang hampir sama dengan masyarakat yang beragama khususnya agama islam seperti ritual sunatan yang mereka lakukan menggunakan symbol dan ritual agama seperti kalimat pembukaan dalam melakukan aktifitasnya yaitu bismillah dan selanjutnya mereka lanjutkan dengan menyebut nama Nabi Adam, dan Nabi Muhammad. kalimat-kalimat tersebut sangat jelas mengarah ke ajaran agama islam namun masyarakat Alifuru sampai sekarang belum beragama, oleh karena itu muncul berbagai pertanyaan bahwa apakah ritual-ritual yang dilakukan masyarakat merupakan suatu perpaduan (integrasi) antara agama dan budaya ataukah pengaruh islam telah masuk dalam tradisi ritual mereka.
\end{abstract}

Kata Kunci: Ritual, Simbol, Integrasi, Agama, budaya.

Pembentukan negara dan bangsa Indonesia tidak menjadikan masing-masing suku bangsa itu manjadi penuh, karena masing-masing tetap mempertahankan identitas kesukubangsaan, tertentu dalam rangka interaksi dalam lingkungan kesatuan-kesatuan hidup yang lebih luas. Seperti di katakan di atas bahwa Bhineka Tunggal Ika yang menjadi motto bangsa Indonesia dan telah di sadari sejak awal. Masyarakat Maluku adalah bagian dari negara kesatuan Indonesia yang terdiri dari sub suku yang memiliki 130 bahasa yang terindikasi dan aktif digunakan sebanyak 117 bahasa. Meskipun masyarakat di daerah maluku ini mencerminkan karakteristik masyarakat yang multikultural. Tetapi pada dasarnya mempunyai kesamaan-kesamaan nilai budaya sebagai suatu masyarakat kolektif. Salah satu di antaranya, adalah filosofis Siwalima yang selama ini telah melembaga, sebagai World View atau cara pandang masyarakat tentang kehidupan bersama. Sehingga di dalam filosofi ini terkadang berbagai pranata 
muncul dan ditemukan di seluruh wilayah Maluku seperti pranata budaya Masohi, Maren, Sasi, Hawear, Pela Gandong, Saniri negeri dan lain sebagainya.

Dalam konteks pembangunan budaya sebagai suatu simbol untuk mengetahui dan membedakan masyarakat berdasarkan suku. Dengan demikian budaya merupakan alat untuk mengetahui dan membedakan suatu suku dengan suku lainnya yang ada di maluku. Walaupun masyarakat di kenal sebagai masyarakat multicultural, tetapi dengan adanya perbedaan-perbedaan tersebut merupakan suatu kewajaran yang pada setiap masyarakat. Sebagaimana telah di katakan di atas bahwa masyarakat maluku dengan kebudayaan dan ratusan sub suku merupakan suatu kesatuan kolektif dengan ratusan pulau yang di tempati masing-masing suku salah satunya adalah suku Alifuru di Desa Leku Kecamatan Namrole Kabupaten Buru Selatan. Dimana masyarakat tersebut masih sangat tertinggal jauh dari perkembangan modernisasi karena mereka hidup di pegunungan namun memiliki budaya dan ritual-ritual sebagaimana masyarakat lainnya dan uniknya sampai sekarang masyarakat Alifuru ini tidak menganut salah satu agama resmi yang ada di Indonesia.

Masyarakat Alifuru yang menempati pegunungan desa Leku Kecamatan Namrole merupakan masyarakat yang masih di lihat alami, dalam arti bahwa hidup mereka masih tergantung pada alam, sebagaimana masyarakat lainnya. Masyarakat Alifuru juga mempunyai berbagai ritual diantaranya ritual sunatan, perkawinan, kematian, dan lainnya. Hal menarik lainnya untuk menjadi focus penelitian adalah seperti dikatakan di atas bahwa masyarakat Alifuru adalah masyarakat yang sampai saat ini belum beragama tetapi mereka mempunyai ritual-ritual yang hampir sama dengan masyarakat yang beragama khususnya agama islam seperti ritual sunatan yang dilakukan masyarakat Alifuru seperti kalimat pembukaan dalam melakukan aktifitasnya yaitu bismillah dan selanjutnya mereka lanjutkan dengan menyebut nama nabi Adam, dan nabi Muhammad. kalimat-kalimat tersebut sangat jelas mengarah ke ajaran agama islam, oleh karena itu muncul berbagai pertanyaan bahwa apakah ritual-ritual yang dilakukan masyarakat merupakan suatu perpaduan (integrasi) agama dan budaya ataukah pengaruh islam telah masuk dalam kegiatan ritual mereka.?. 


\section{METODE PENELITIAN}

Pendekatan yang digunakan dalam penelitian ini adalah dekriptif, dengan pendekatan kualitatif. Dengan menjadikan masyarakat sebagai unit analisis dan pengamatan. Pendekatan kualitatif adalah upaya untuk memperoleh data valid dari beberapa informan, yaitu; Para tokoh adat, mantan raja, perangkat saniri, dan tokoh masyarakat lainnya yang relevan dengan fokus penelitian, sekaligus menentukan informan kunci. Pengumpulan data bertumpu pada tiga cara, yaitu wawancara: studi dokumen yang terkait dengan persoalan penelitian dan didukung dengan hasil observasi penelitian.

\section{HASIL PENELITIAN DAN PEMBAHASAN}

Pembahasan pada bagian ini, penulis fokus pada hasil temuan lapangan selama penelitian pada masyarakat Alifuru yang ada di Desa Leku Kecamatan Namrole Kabupaten Buru Selatan. Desa Leku adalah desa yang mempunyai struktur adat yang lengkap. Terpisah dari struktur pemerintahan dimana setelah dilantik secara pemerintahan kemudian dilantik secara adat.

Struktur Pemerintahan terdiri dari: (1) Kepala desa adalah pejabat pemerintahan sekaligus kepala adat.(2). Kepala dusun (3). Kepala soa. (4).Tuan tanah,biasa juga disebut tuan adat.(5).kepala adat.(6).Molesi,biasa juga disebut kapitan yaitu orang yang dianggap mempunyai kekuatan-kekuatan gaib dan mempunyai kekebalan tubuh. (7).Tukang-tukang yang diberi tugas khusus untuk memimpin acara ritual-ritual adat, tukang juga dikenal sebagai mauweng. Status tukang dalam suku alifuru memiliki keistimewaan karena dianggap dekat dengan hal-hal magis, ahli pengobatan. (8). Marinyo, juru bicara kepala Desa.

\section{Sejarah dan Perkembangan Masyarakat Alifuru}

Pada dasarnya pegunungan kepulauan Buru Selatan dihuni oleh tujuh Soa, yaitu soa wailua, soa waitemun, soa waigira, soa gewagit, soa wahidin, dan soa wakibun. Diantara soa-soa tersebut diatas soa wailua, soa waitemun, dan soa wagira adalah soa yang menempati pegunungan Leku. lewat kesempatan bersama sebagian dari ketiga soa tersebut turun ke lokasi tingkabi untuk membuka pemukiman baru namun upaya ini 
tidak bertahan lama karena faktor-faktor tertentu. kemudian mereka melanjutkan ke lokasi pemukiman Leku hingga sekarang. Sejarah mencatat bahwa dari ketiga soa tersebut muncul beberapa marga yaitu dari soa waitemun muncul marga norlatu, soa wailoa muncul marga latubual dan soa wagira muncul marga tasani, sebagian soa yang turun kepantai langsung memeluk agama Islam sedangkan sebagian yang masih menempati pegunungan desa leku sampai sekarang belum beragama.

\section{Bentuk-bentuk Ritual Masyarakat Alifuru}

Bentuk-bentuk ritual yang digunakan masyarakat Alifuru adalah sebagai berikut:

\section{a. Ritual Kelahiran (Emlomon Enmanat)}

Dalam masyarakat Alifuru apabila seorang anak lahir maka anak itu di tangani oleh biang (Dukun bersalin) biang menangani sianak yang baru lahir dan membuat ramuan-ramuan obat untuk ibu yang baru melahirkan setelah itu biang memotong tali pusat sibayi dengan menggunakan bambu yang masih muda, penggunaan bambu menunjukan bahwa masyarakat Alifuru ini masih hidup dengan cara yang alami, walaupun pada saat ini mereka sudah mengenal alat-alat tajam seperti pisau, silet dan lain-lain.

Setelah proses penanganan pemotongan pusat dan penanganan ari-ari bayi maka bayi akan menetap di dalam rumah selama dua bulan atau lebih tergantung kemampuan orang tua. Tujuan dari ritual adalah untuk mengharapkan bayi tersebut umur panjang, sehat dan terhindar dari mara bahaya, yang ada di lingkungan tersebut.

\section{b. Ritual Sunatan (E'nei)}

Ritual sunatan dalam bahasa Alifuru di sebut E'nei ritual ini di lakukan pada saat seorang anak beranjak dewasa. Malinowski Radelife Brow menggunakan pernyataan Durkeim bahwa agama mereflesikan struktur dari sistem sosialnya dan fungsi untuk memelihara sistem tersebut dari masa ke masa.

Ritual sunatan merupakan ritual yang kedua di lakukan masyarakat Alifuru yaitu setelah ritual kelahiran sudah merupakan suatu keharusan bagi suku Alifuru sejak turuntemurun bahwa seorang anak beranjak dewasa harus di sunatkan (E'nei) apabila tidak di laksanakan anak tersebut akan terkena kualat dari para leluhur berupa kutukan di timpa bencana sakit, tidak mempunyai keturunan dan tidak diakui sebagai kelompok 
masyarakat Alifuru, serta tidak melaksanakan adat istiadat dan menurut anggapan mereka orang yang belum di sunat adalah orang yang masih dalam keadaan kotor.

Seperti pada ritual kelahiran di mana masyarakat Alifuru itu masih terlihat alami dalam segala aktifitasnya, demikian juga pada ritual sunatan. Dalam melakukan ritual sunatan masyarakat Alifuru masih menggunakan cara-cara yang alami untuk proses penyunatan tersebut, simbol-simbol tertentu yang muncul pada saat melakukan ritual seperti benda-benda atau bahasa yang keluar pada saat melakukan ritual menunjukan identitas diri mereka sebagai masyarakat yang masih bergantung pada alam.

Dengan demikian dalam melakukan ritual sunatan yang di lakukan masyarakat Alifuru mempunyai makna dan tujuan tertentu dalam melakukan ritual tersebut, berbagai benda-benda yang alami seperti bambu muda, piring tua, lenso dan sebagainya merupakan simbol-simbol yang pernah ada sejak nenek moyang mereka dan sampai saat ini. Hal ini dapat juga terlihat pada masyarakat jawa bahwa dunia mengandung simbolisme dan melalui simbol-simbol inilah seseorang merenungkan kondisi dengan manusia (habluminannas) dan dengan tuhan (habluminallah) seperti tertulis dalam surat cemhini bahwa jika engkau ingin menembus dunia realitas maka hendaklah masuklah kedalam simbol.

Tahap pelaksanaan ritual sunatan di mulai dengan mengambil tukang dengan cara belah pinang ( Faka fua) yaitu penyampaian maksud mengundang orang yang akan melakukan upacara E'nei yang di sebut tukang, ketika tukang tiba di sambut dengan meriah dengan berbagai tarian adat seperti cakalele. Hone (Berbalas pantung dengan bahasa daerah) pada saat bermalam dengan tukang, tukang akan dihibur dengan syairsyair berbahasa daerah yang di sebut Inafuka sampai pagi. Kemudian paginya anak yang mau di sunatkan di antar ke orang tuanya, sebelum acara sunat di mulai. Selanjutnya dari rumah orang tua dari anak-anak yang mau di sunatkan di bawa ke mata air terdekat dan langsung di rendam sebatas pusat selama kurang lebih enam jam kemudian marinyo akan melakukan pengecekan terhadap anak-anak tersebut sebanyak 3 kali, kemudian tukang yang berpakaian rapi langsun menuju ke mata air tempat di laksanakan ritual sunatan di iringi tifa tomo (bunyi-bunyian tifa) dan pisau yang telah di siapkan untuk melakukan ritual sunatan di taruh di dalam sebuah piring tua kemudian di 
bawa bersama-sama tukang ke tempat sunatan, tujuannya apabila terjadi pendarahan piring tersebut digunakan untuk menadah tetesan darah yang keluar kemudian tukang melaksanakan kegiatan sunatan dengan posisi yang telah disiapkan yaitu di atas batu yang telah di susun rapi dalam posisi duduk dengan peralatan yang di sebut Taraat (yaitu bambu yang telah disediakan untuk mengelus kemaluan dengan ujung yang lancip) di masukan setelah pisau yang telah disiapkan langsung di bila dengan mantra menurut Logat Nurlatu (54 tahun) sebagai berikut :

"Bismillah masih sama uhat wa sama uhat nabi Adam sama uhat"

Artinya : Demi nama Tuhan air laut dan air darat membagi urat-urat nabi Adam menyatukan urat.

Namun apabila kemaluan anak masih mengelurkan darah maka mantra yang mereka ucapkan adalah sebagai berikut:

“Bismillah kunci rahang wete rahang nabi Adam kunci rahang “

Artinya : Dengan nama Tuhan kunci darah stop darah nabi Adam stop darah.

Tapi ketika kemaluan yang masih darah maka mantranya sebagai berikut juga:

"Bismillah masih raja wai raja masih tumbal wai tumbal seperti nabi Muhammad" Artinya :Raja laut raja darat kasih dingin luka seperti nabi Muhammad.

Dalam mantra-mantra di atas selain mengucapkan Bismillah masyarakat Alifuru juga memohon kepada air yang ada di laut dan air yang ada di darat untuk menyetopkan darah anak yang di sunatkan tadi kemudian mereka menyebut para nabi yaitu nabi Adam atau juga nabi Muhammad dengan tujuan untuk mendinginkan atau menyatukan urat anak yang di sunat dengan demikian mereka sudah menggabungkan kepercayaan mereka terhadap para nabi dan alam sebagai pengantara permohonan mereka, oleh karena itu antara Tuhan, nabi dan Alam menurut masyarakat ini sudah saling berhubungan, namun yang menjadi keganjalan peneliti. Tuhan bagi mereka adalah sesuatu kalimat yang muncul hanya pada saat ritual sunatan dan kematian, tidak dalam kehidupan sehari-hari mereka. Makna Tuhan bagi mereka hanya pada saat ritual sunatan dan kamatian saja.

Kemudian tukang beserta anak-anak kembali ke rumah dan di sambut oleh keluarga dengan berbalas pantun (Hobe) salah satu pantun tersebut adalah 
Tukang datang dengan anak-anak yang sudah di sunat.

rasa sayang kepada anak-anak

tukang tiba di rumah dengan jiwa dan umur selamat.

Setelah berbalas pantun selesai rombongan dipersilahkan masuk, sebelum dipersilahkan masuk ke rumah salah satu dari rombongan mengucapkan salam yaitu "salam leku" kemudian yang menunggu menjawab "leku salam” barulah tukang dan rombongan di persilahkan masuk ke rumah.

\section{c. Makna Ritual Sunatan}

Susane langer memperlihatkan bahwa ritual merupakan ungkapan yang bersifat logis daripada bersifat psikologi dimana ritual memperlihatkan tatanan atas simbolsimbol yang diobjekan simbol itu megungkapkan perilaku dan perasaan serta membentuk disposisi pribadi dari para pemuja yang mengikuti modelnya masingmasing.

\section{d. Ritual Perkawinan (Enhekat)}

Perkawinan merupakan suatu nhal yang sangat penting bagi kehidupan manusia dimana melalui perkawinan atau individu tersebut dapat menyalurkan naluri seksnya secara baik tanpa mempengaruhi moralitas orang lain melalui perkawinan juga seorang anak yang lahir dengan struktur keluarga yang lengkap, oleh karena itu setiap individu yang dalam menjalani hidupnya pasti melewati masa dimana ia harus dipertemukan dengan pasangan hidupnya sehingga berbagai kebiasaan atau ritual-ritual dilakukan untuk mengesahkan dan menyatukan sebagai suami istri yang sah seperti masyarakat alefuru juga merupakan masyarakat yang menggelar ritual perkawinan dengan kebiasaannya sendiri sebagaimana penulis dapatkan dilapangan bahwa pada umumnya perkawinan masyarakat Alifuru terbagi menjadi dua yaitu perkawinan masuk minta dan perkawinan lari kawin.

\section{Perkawinan Masuk Minta}

Proses perkawinan masuk minta bagi suku Alifuru di laksanakan dengan cara sasih rumah, yaitu anak perempuang yang di minang mulai berusia 5 tahun ke atas bahkan menurut Logat Nurlatu(66 tahun)Anak yang masih dalam kandungan dia pu ibu itu kalau katong sudah tau dia perempuan maka yang mau kawindengan ank itu harus 
sudah memberikan tanda dengan cara menikam tumbak di bawa pasir belakang Ibunya dan ketika anak itu lahir sampai usia lima tahun maka laki-laki yang mau kawin dengan anak itu harus membiayai anak itu. dalam proses ini sebenarnya ketika bayi yang masih dalam kandungan ibunya dan sudah di ketahui bayi tersebut adalah perempuan maka sasi rumah mulai berlaku dengan cara orang atau laki-laki yang ingin meminang bayi tersebut ketika besar meminakam tumbak di tanah belakang sang ibu hamil tersebut kemudian menunggu sampai anak tersebut lahir pas 5 tahun ke atas maka cara selanjutnya adalah galang walang (seorang anak di beri tanda ikatan berupa uang dan barang) atau di sebut prata. Dalam arti bahwa anak tersebut akan di biayai oleh laki-laki tersebut sehinga anak berusia 17 barulah di lakukan upacara perkawinan, namun menurut realita yang peneliti luhat di lapangan bahwa dalam tahap penunguhan ini peneliti mendapatkan banyak anak yang belum mencukupi usia 17 tahun sudah menikah. oleh karena tahapan - tahapan dalam proses perkwinan masyarakat Alifuru adalah

\section{Tahap sasi rumah}

Sebagaimana dijelaskan di atas bahwa sasi rumah merupakan proses pemingan anak perempuan sejak berusia 5 tahun bahkan dari kandungan ibu, dengan cara dalam walang yaitu pemberian tanda berupa uang atau barang pada keluarga anak tersebut atau pihak laki-laki yang meminang anak tersebut membiyayai hidupnya hinga anak tersebut berusia 17 tahun.

\section{Tahap fakafua (belah pinang)}

Dalam tahap ini keluarga kedua belah pihak membicarakan harta dan pelaksanaan perkawinan secara adat, yaitu perkawinan di laksanakan selama 1 minggu kemudian anak perempuan tersebut di bawah kembali ke rumah suaminya dengan cara membawakan sejumlah uang dan barang di bawa serta secara adat ke rumah suaminya dengan demikian diresmikan kehidupan menjadii suami istri.

Dalam proses fakafua selain kedua belah pihak bermusyawarah untuk merencanakan hal-hal yang berkaitan dengan perkawinan yang di lakukan di rumah pihak perempuan dengan mengumpulkan harta fena yaitu 7 buah kain putih atau kain berang(merah) yang di taruh di piring (hormaten pito) atau 7 buah kain berang yang di 
ikat di tumbak (titir pito) fungsi dari hormatan pito atau titir pito adalah untuk menggantikan kain gendong ibunya, selain itu ada juga harta (flolet) masyarakat Alifuru terbagi menjadi 2 (dua).

1. Snil mata, Yaitu harta tetap yang dibebankan pada pihal laki-laki (harta wajib) di mana harta ini tidak bisa kurang dari permintaan pihak perempuan.

2. Harta bunga, yaitu harta tambahan dari pihal lak-laki biasanya harta ini berupa segala sesuatu yang di butuhkan oleh pihak perempuan mulai dari ujung kaki sampai ujung rambut dan perlengkapan dapur.

Dalam islam mahar adalah harta yang di berikan pihak calon suami kepada calon istrinya untuk di miliki sebagai penghalal hubungan mereka. Mahar ini menjadi hak istri sepenuhnya sehingga bentuk dan nilai mahar ini pun sangat di tentukan oleh kehendak istri bisa saja mahar itu bebentuk uang, benda atau jasa tergantung permintaan pihak istri. Mahar ini pada hakikatnya di nilai dengan nilai uang sebab mahar adalah harta bukan sekedar simbol belaka.

\section{Tahap pelwani}

Proses pelwani yaitu perempuan di hiasi dengan pakaian yang bagus di dalam sebuah kamar yang dihiasi oleh kerabat perempuan dengan masing-masing membawa kain untuk menghiyasi kamar tersebut dengan harapan ketika dari pihak laki-laki memasuki kamar itu maka akan membuka kain tersebut satu persatu dan menggantikan dengan barang lain seperti kuali masak.

\section{Tahap Nyoltuha}

Tahap nyoltuha adalah acara membawa perempun ke pihak laki-laki dan lakilaki melakukan persiapan yang mantap untuk menyambut pihak perempuan, dalam acara ini terdapat sebuah acara yang di sebut kore sanad di mana setelah perempuan tiba di rumah kerabat laki-laki, telah mempersiapkan berbagai masakan untuk menyambut keluarga pihak perempuan. namun dalam acara ini terkesan semacam acara makan puji di mana setiap makan atau minum yang di makan oleh pihak perempuan sudah dikenakan harga permakanan tersebut. Jadi misalnya dari pihak laki-laki memakan daging sapi maka harganya harus dua ekor daging sapi atau meminum segelas sirup misalnya maka harga satu gelas sirup tersebut bisa menyapai dua ratus ribu. 


\section{Perkawinan Lari Kawin}

Pada umumnya perkawinan lari kawin untuk masyarakat Alifuru adalah utuk mengurangi harta dalam perkawinan seperti kawin masuk minta, proses atau tahap perkawinan lari kawin adalah di mulai dengan laki-laki yang ingin melarikan perempuan yang dinikahkan maka harus menaru satu buah gong, satu buah tumbak dan satu buah parang di tempat tidur perempuan yang akan di bawah pergi kemudian lakilaki membawa pergi perempuan secara diam-diam ketika orang tua dari perempuan mengetahui kalau anaknya tidak ada di bawah laki-laki dan orang tua tersebut marah atau emosi maka pihak laki-laki harus menambah satuh buah gong ke tempat tidur perempuan lagi dengan cara snet" yaitu pihak laki-laki masuk ke pihak perempuan untuk pemecahkan persoalan laki-laki dan perempuan yang telah lari kawin. Namun ketika dari pihak perempuan belum juga sepakat maka hal selanjutnya yang di lakukan adalah dengan cara" gebawasan" yaitu utusan dari pihak laki-laki dan perempuan untuk merudingkan persoalan tersebut, adalah orang di anggap jabatannya lebih tinggi seperti kepala soa atau kepala desa, setelah pertemuan antara 2 gebawasan ini ketika dari keputusan mereka untuk mengawinkan kedunya maka perkawinan akan dilanjutkan dengan proses seperti perkawinan masuk minta namun masalah harta seperti snil mata (harta tetap) dan harta bunga (harta tambahan) tidak berlaku dalam perkawinan ini.

Dalam perkawinan suku Alifuru juga dilarang kawin dengan kerabat keluarga dekat seperti perkawinan antara bapak dengan anak perempuanya, ibunya dan anak lakilakinya, kakak dengan adik perempuan, pelanggaran semacam ini menurut kepercayaan mereka akan mendapat bencana yang besar pada masyarakat bencana tersebut berupa topan, banjir, gempa bumi, dan lain-lain. bencana- bencana ini hanya di singkirkan dengan jalan menghukum pelaku yang membuat pelanggaran pada perkawinan. Selain itu pula perkawinan antara paman dan kemenakan perempuan, bibi dengan kemenakan laki-lakinya yang bukan semarga bagi suku Alifuru ini merupakan larangan (pamali) yang paling besar, demikian juga dengan anak-anak dua saudara laki-laki ternyata tidak diperbolehkan karena bertentangan dengan hukum adat. Tujuan ritual perkawinan adalah untuk menjadi tempat pemenuhan seks dan untuk mendapatkan keturunan

\section{Ritual Kematian (Matat)}


Seperti halnya masyarakat pada umunya, kematian merupakan sesuatu yang datang secara alami dan semua mahluk pasti mengalami kematian. Bagi masyarakat Alifuru kematian merupakan hal yang sakral, di mana terjadi perpisahan yang selamalamanya antara orang yang ditinggalkan dan orang yang pergi tak pernah kembali. Dalam menangani orang yang meninggal masyarakat Alifuru seperti juga masyarakat lainya yang manggunakan tanah sebagai tempat kembalinya semua orang maka masyarakat Alifuru juga mengenal apa yang di sebut kuburan.

Malinouwski menunjukan arti pentingnya, peribatan-peribadatan tertentu bagi individu maupun secara langsung bagi masyarakat tertentu,karena itu peribadatanperibadatan yang berkaitan dengan kematian yang mendapat perhatian besar dari Malinouwski sebagai ssesuatu yang antara lain timbul dari rasa takut setiap orang terhadap kematiannya sendiri, tetapi juga sebagai sesuatu yang mengekspresikan konflik berbagai emosi orang-orang yang masih hidup terhadap orang-orang yang meninggal, yang masih mengharapkan bisa mempertahankan bahkan juga memutuskan ikatan ikatan dengannya sesuai dengan struktur sosial tertentu. Bagi masyarakat Alifuru tahapan-tahapan dalam ritual kematian antara lain :

\section{Tahap persiapan ritual mandi kelapa}

Pada tahap ini semua keluarga mayat berkumpul di malam hari untuk memusawarahkan kegiatan yang akan di laksanakan besok pada tahap ini juga keluarga mayat memasak untuk menjumu para kerabat yang datang, berbagai barang dan perlengkapan disiapkan bahkan kue untuk hidangan pagi pun telah di siapkan. Besok paginya sekitar jam 05,30 salah seorang dari mereka yang sudah berumur lebih tua menaruh sebuah kelapa yang di ambil dari dalam rumah mayat dan ditaruhkan di muka jalan masuk tempat tinggal mereka, menurut Sami Nurlatu (32 tahun) "Fungsi dari kelapa itu adalah untuk mengusir segala macam malapetaka yang datang menimpah tempat mereka". Sikap keagamaan terbentuk dari dua faktor yaitu faktor interen dan eksteren, faktor interen menggambarkan manusia sebagai homo religius (mahluk beragama) karena manusia sudah memiliki potensi untuk beragama. Potensi tersebut bersumber dari faktor interen manusia dalam aspek kejiwaan manusia seperti naluri, akal, perasaan maupun kehendak dan sebagainya. Sebaliknya teori ke dua menyatakan 
bahwa jiwa keagamaan manusia terdorong untuk beragama karena pengaruh faktor luar dirinya seperti rasa takut, rasa ketergantungan, ataupun rasa bersalah, faktor -faktor inilah yang menurut pendukung teori tersebut mendorong manusia menciptakan suatu tata cara pemujaan yang kemudian dikenal dengan ritual.“ oleh karena selain menggantungkan kelapa di depan jalan orang yang ditugaskan itu juga telah berbicara atau memohon pada alam serta orang yang meninggal, untuk tidak mengganggu kehidupan mereka dan terhindar dari malapetaka yang nantinya menimpah mereka sehingga buah kelapa disimbolkan sebagai penangkal malapetaka, setelah itu para kerabat yang datang serta sanak keluarga yang menikmati hidangan yang telah di sediakan dan setelah itu mereka mengerjakan pekerjaan yang di berikan kepada mereka misalnya seperti pemarutan kelapa ditugaskan kepada laki-laki setelah jam 12,30 kelapa yang tadinya di taruh di muka jalan di ambil dan di bawakan ke sungai dengan tiga orang perempuan dan tiga orang laki-laki dan sesajen berupa makanan. Menurut Logat nurlatu (66 tahun)

kelapa itu nanti katong bawa ka sungai dengan tiga orang laki-laki dan tiga orang perempuan dan bawa makan untuk orang yang meninggal,nanti disungai katong panggil mayat dan tanda tandanya nanti muncul lalat yang hinggap lama di makanan tersebut maka itu dalah simayat.

Setelah sampai di sungai mereka membuat paruh yang terbuat dari bambu kering dan mengambil daun pisang dan beberapa jenis daun yang berbentuk lebar dan panjang, setelah itu mereka mengupas kelapa memarutnya dengan parutan yang terbuat dari bambu tersebut dengan beralaskan daun pisang. Setelah memarut kelapa salah seorang atau keluarga terdekat mayat membagikan sesajen yang di bawa dari rumah dengan cara sebagian untuk simayat dan sebagian lagi untuk pasangan yang ikut, setelah itu mereka semua duduk mengelilingi sesajen tersebut dan kakak atau bapak dari simayat memanggil mayat dengan bahasa mereka yang menurut Logat Nurlatu panggilanya artinya "Datang sudah makanan telah disediakan untuk kamu datang dan makan sudah".

Panggilan itu selama tiga kali apabila belum ada tanda untuk simayat datang maka orang lebih tua dari mereka akan mengulangi panggilan tersebut satu kali setelah itu mereka semuanya diam dan menunggu kedatangan simayat. Pada beberapa saat 
kemudian, hadir seekor lalat yang hinggap di sesajen yang telah disediakan, menurut pemahaman mereka di antara lalat-lalat yang menghinggapi makanan tersebut satu di antaranya adalah simayat, di mana apabila lalat tersebut lama menghinggapi makanan maka lalat tersebut adalah simayat. Setelah diketahui bahwa si mayat telah makan, maka makanan yang dipisahkan itu langsung dinikmati oleh enam orang pasangan yang ikut itu.

Setelah acara makan-makan, maka kakak atau bapak dari si mayat tersebut membagikan kelapa yang diparut itu ke masing-masing daun yang telah disediakan, masing-masing orang mendapatkan sedikit kelapa yang sudah ditaruh di dalam daun yang berbentuk lebar dengan ditutupi dengan daun yang bentuknya agak memanjang, sesudah itu mereka menuju kedalam sungai dan membuat barisan dari yang tua hingga kepasangan-kepasangan tersebut, kemudian yang tua mulai memberikan arahan serta membuat suatu permohonan kepada mayat tersebut untuk terhindari dari malapetaka.

Tahap Ritual Hari (Samola)

Tahap ini adalah ritual inti dimana para keluarga dari jauh pun tiba untuk membuat samola (hari). Pada tahap ini masyarakat Alifuru memasak sebanyakbanyaknya untuk acara samola tersebut. Setelah seluruh masakan masak maka mereka memisahkan makanan untuk mayat, makanan yang disiapkan untuk mayat mereka taruhkan didalam kamar kemudian beberapa orang dari mereka masuk kedalam kamar dan duduk mengelilingi makanan untuk memanggil mayat tersebut, seperti pada tahap upacara mandi kelapa panggilan yang sama pula dilakukan di kamar dimana para keluarga tersebut memanggil-manggil mayat untuk datang menikmati makanan yang telah disediakan dengan di tandai kedatangan seekor lalat yang menghinggapi makanan tersebut.

\section{Makna Ritual bagi Masyarakat Alifuru}

Suku Alifuru adalah masyarakat yang sampai saat ini belum beragama. Apabila kita katakan masyarakat ini menganut kepercayaan animisme realitanya masyarakat ini tidak menyembah roh-roh (Anima) tersebut. Dalam kehidupan masyarakat Alifuru mereka mengenal dan meyakini adanya Tuhan dan menurut mereka Tuhan tidak beranak dan tidak pula diperanakan. Namun kata tuhan (Alastala) bagi mereka hanya 
sekedar ucapan atau kalimat awal dalam melakukan ritual sunatan dan kematian saja, mereka tidak pernah meyakini tuhan dalam kehidupan sehari-hari mereka.

Dalam melakukan ritual sunatan dan kematian mereka mengawali doa (Lifaten) mereka dengan kalimat Bismillah kemudian isi dari Lifaten (doa) mereka dan seterusnya mereka menyebut nama nabi Adam dan nabi Muhammad, seperti doa (Lifaten) yang digunakan dalam ritual sunatan.

"Bismillah masih sama uhat wa sama uhat nabi Adam sam uhat"

Artinya : Nama tuhan air laut dan air darat membagi urat, nabi Adam menyatukan urat.

Doa atau Lifaten diatas menunjukan bahwa mereka menyebut nama tuhan dan kemudian nama nabi Adam. Menurut mereka nabi Adam adalah nabi yang tidak bisa menyebut bismillah secara sempurna, yang mampu menyebut kalimat bismillah secara sempurna hanya nabi Muhammad SAW. Sehingga mereka berpegang hanya kepada nabi Adam yang menurut mereka dunia nabi Adam masih dalam alam reden yaitu alam antara terang dan gelap. Demikian juga mereka merasa masih ada dalam alam reden yaitu alam antara terang dan gelap pula. Dalam ritual kematian ketika mereka melakukan acara puji-pujian (Babeto) masyarakat Alifuru juga membakar kemeniyan dengan tujuan asap kemeniyan adalah untuk membawa doa (Lifaten) mereka kepada si mayat, sehingga si mayat tidak lagi mengganggu kehidupan keluarga mereka.

Sehingga walaupun masyarakat ini mengakatan tidak menjadi penganut agama apapun dan segala ucapan yang dilakukan dan diucapkan baik berupa bismillah dan nama para nabi semata-mata dari nenek moyang mereka tidak mengakui bahwa pengaruh islam sudah masuk pada lingkungan mereka lewat pembauran atau interaksi antara sesama saudara-saudara mereka yang telah turun kepantai dan menjadi penganut agama Islam. Kalimat bismillah dan penyebutan nama nabi bagi mereka merupakan kalimat-kalimat yang sudah di ucapkan secara turun-temurun.

Kemudian ritual sunatan Islam pun diwajibkan sunatan bagi laki-laki dan perempuan dimana ritual sunatan merupakan ritual atau kebiasaan orang yang pertama kali dipraktekan pada zaman nabi Ibrahim As sebagaimana rasulungllah Saw bersabda yang Artinya : Ibrahim khaliblurahman (kekasih Allah telah berhitan setelah ia berumur 
80 tahun ia berkhitan dengan menggunakan gadum (semacam kapak) (Hr Bukhari dari Abi ra.). Sama dengan masyarakat Alifuru, sunatan merupakan sesuatu yang diwajibkan ketika seorang anak beranjak dewasa. Apabila tidak dilaksanakan maka anak tersebut akan terkena kualat leluhur berupa kutukan, bencana, sakit, tidak mempunyai keturunan dan tidak diakui sebagai kelompok satuan Alifuru, serta tidak melaksanakan adat istiadat. Karena menurut anggap mereka bahwa orang yang belum disunatkan masih dalam keadaan kotor.

Agama bukanlah sesuatu yang penting bagi mereka, agama bukanlah sebagai jalan atau petunjuk kehidupan mereka. Tapi alamlah yang menjadi petunjuk bagi mereka walaupun tanpa di sadari setiap aktifitas mereka melewati bagian dari unsurunsur agama namun mereka tidak menyadari itu sebagai unsur agama. Yinger mengemukakan bahwa dalam masyarakat modern masih terdapat orang-orang yang tidak beragama atau tidak memeluk kepercayaan apapun serta tidak ikut dalam peribadatan apapun namun, mereka mempunyai nilai mutlak untuk menopang kehidupan mereka dan mengidentifikasikan nilai-nilai yang beraneka ragam sebagai pengabdian pencarian kebenaran.

Ritual dan kepercayaan masyarakat Alifuru tarhadap para nabi merupakan sesuatu yang di wariskan nenek moyang bukan sebagai unsur agama, sehingga mereka mengembangkannya demi untuk melestarikan budaya nenek moyang mereka, sehingga masyarakat Alifuru merupakan masyarakat yang hidup tanpa kesadaran beragama, apa yang mereka lakukan hanya sekedar mengikuti apa yang di lakukan oleh nenek moyang mereka. Alam merupakan hal yang paling penting bagi masyarakat Alifuru karena menurut mereka alam adalah penentu hidup mereka bukan agama.

\section{KESIMPULAN}

1. Bentuk-bentuk ritual yang mereka miliki berdasarkan hukum yang kuat dari adat nenek moyang mereka secara turun-temurun yang harus dilaksanakan untuk proses inisiasi atau peralihan seorang individu dari waktu ke waktu atau dari lingkungan lama ke lingkungan yang baru dengan simbol-simbol tertentu.

2. Masyarakat Alifuru merupakan masyarakat yang tidak beragama namun mereka 
mengenal tuhan, para nabi seperti nabi Adam dan nabi Muhammad, dan mempunyai bentuk-bentuk ritual tetapi dalam mengarungi kehidupan mereka bukan berdasarkan atas moralitas keagamaan, melainkan segala tindakan perbuatan nenek moyang yang mereka pegang dan menjadi pengatur aktifitasnya dan alam adalah segala-galanya bagi mereka dalam mengarungi kehidupan.

\section{DAFTAR PUSTAKA}

Arikunto S. Prosedur Penelitian Suatu Pendekatan Praktek, PT, Rineka Cipta: Jakarta 1998

Bahta, Sri Handayani, Ritual Sunatan Suku Alifuru di Desa Leku Kecamatan Namrole, Skripsi Stain Ambon 2006

Betty, Andrew, Variasi Agama di Jawa, Suatu pendekatan antropologi, Cet I. PT. Grafindo Persada, Jakarta, 2000

Departemen Agama RI, Al Qur'an dan Terjemahannya, (Proyek Pengadaan Kitab Suci Al Qur'an dan Terjemahan, 1981/1982

Dhavamony Mariasusai, Fenomenologi Agama.Cet VII, PT. Kanisius Yogyakarta:1973

Elly M. Setiadi.Ilmu Sosial Budaya Dasar Cet IV. PT. Prenada Media Group: Jakarta. 2008

http;//sanaky.com/wp-content-oploods/2009/02/03-Hubungan agama dan kebudayaan.pdf

Jalaludin, Psikologi Agama, cet. XII. PT. Grafindo Persada; Jakarta: 2009

Joko Widgolho, Ilmu Budaya Dasar, Bhineka Aksara, Jakarta, 1988

Kahmad, Dadang. Sosiologi Agama, Cet II, PT Remaja Rosdakarya: Bandung. 2002

Koentjaraninggrat, Ritus Peralihan di Indonesia. Cet I, PT. Balai Pustaka Jakarta:1985

Latuconsina, Abd Khalik. Pataheri dan posuno :Ritual Inisiasi Suku Nuaulu. Cet I, Grha Guru Printika :Jogjakarta,2011

Mulyana, Dedi. Metode Penelitian Kualitatif: Paradigma Baru Ilmu Komunikasi DanIlmu Sosial Budaya, Cet I, Remaja Rosdakarya Bandung: 2001

Rafael Ragamukan, Manusia dan Kebudayaan, Cet I, PT. Rineka Cipta. Jakarta, 2000.

Supriyono, Iman, Metode Penelitian Sosial Agama, Cet I, PT. Remaja Rosdakarya. Bandung: 2001

Saefudin, Ahmad Pedyani. Antropologi Kontemporer suatu pengantar kritis mengenai paradigma, Cet. II. PT. Prenada Media Grup. Jakarta, 2006

Soekanto, Soerjono, Sosiologi Suatu Pengantar. Cet VII, PT. UI Press: Jakarta, 1969 